\title{
Do Government Positions Held by Women Matter? A Cross-National Examination of Female Ministers' Impacts on Women's Political Participation
}

Shan-Jan Sarah Liu

Smith College

Lee Ann Banaszak

The Pennsylvania State University

Political representation is considered important in democracies because it establishes the legitimacy of political institutions and helps governments respond to their citizens (Dovi 2014). In recent years, the inclusion of women in political institutions is also recognized to encourage civic engagement among citizens (Barnes and Burchard 2012; Campbell and Wolbrecht 2006; Kittilson and Schwindt-Bayer 2010; Pearson and Dancey 2011; Wolbrecht and Campbell 2007). However, in exploring this effect of representation, most scholars focus on women's legislative presence, although descriptive representation could be important in many places in the polity. In particular, evidence suggests that increasing numbers of women in cabinets or executives have substantial impact on the political office and policy making (Borrelli 2002; Davis 1997; Reynolds 1999). Yet women's presence in the legislature is not necessarily predictive of representation in the

Published by Cambridge University Press 1743-923X/16 \$30.00 for The Women and Politics Research Section of the American Political Science Association.

(C) The Women and Politics Research Section of the American Political Science Association, 2016 doi:10.1017/S1743923X16000490 
cabinet. While it is reasonable to assume that female legislators might be similar in several ways to female ministers, in many countries, clear differences exist between these two groups. Female legislators, overall, still have few opportunities to become members of cabinets despite the increased presence of women in cabinets, although this is less true in some Latin American countries (Escobar-Lemmon and Taylor Robinson 2005).

This article examines the relative influence of female ministers compared with women in parliament on citizens' civic engagement, focusing particularly on how distinctions in the two types of representation have differential effects on political participation. We categorize political activity by how conventional the action is, based on its costs, risks, and connections to electoral institutions, when evaluating the influence of female cabinet members on civic engagement. We begin by discussing the role model effect and its impact on citizens' participation. We then compare women's representation with that in the cabinet. Next, we theorize how differences between legislative and ministerial representation might result in differential effects on the distinctive forms of political participation. After presenting our hypotheses and describing our data and methods, we present and interpret our findings. We conclude by discussing the implications of these findings for future research.

\section{HOW WOMEN IN POLITICAL OFFICE INCREASE POLITICAL PARTICIPATION}

The lack of gender equality in political leadership remains a fundamental problem, as women continue to be largely underrepresented in legislatures and cabinets (Schwindt-Bayer and Mishler 2005). According to the InterParliamentary Union (2015), on average worldwide, women constitute $22.1 \%$ of upper and lower legislative houses combined. The percentage of women in lower houses also varies extensively among democracies, ranging from $63.8 \%$ in Rwanda to $0 \%$ in several countries. The dearth of women's political representation raises concerns about how such a deficiency affects citizens. Mansbridge (1999), for example, suggests that without descriptive representation, communication with officials by underrepresented citizens might be impaired by a lack of attention from elected officials or feelings of distrust among citizens. She notes that the absence of descriptive representation might make the underrepresented 
feel like second-class citizens or decrease the legitimacy of the polity for excluded groups. Other authors also find that descriptive representation affects disadvantaged groups' ability to express their opinions and participate in politics (Atkeson 2003; Atkeson and Carillo 2007; Burns, Schlozman, and Verba 2001).

Women's descriptive representation can have four specific effects on women's political participation. First, increases in women's descriptive representation may alter women's perceptions of the political system. In a system in which they see few women represented, women may perceive the system as not welcoming women or interpret that women do not have the characteristics that lead to success in that particular arena. Thus, increased representation of women serves as an indicator that politics is not just a “man's game" (Verba, Burns, and Schlozman 1997). That is, the inclusion of women in high elected office signals that women can and should be participants in the political process (Burns, Schlozman, and Verba 2001; Carroll 1994; Reingold 2000). This may be one way that women's descriptive representation in the United States and cross-nationally, defined either by a female candidate running for office or by the percentage of women in a country's legislature, inspires women, particularly girls, who are still in the political socialization stage, to participate more in politics (Campbell and Wolbrecht 2006; Wolbrecht and Campbell 2007).

Similarly, the example of successful female politicians, like women leaders in other professions (see, e.g., Marx and Roman 2002; Nixon and Robinson 1999), is particularly necessary to indicate to other women that there are opportunities for success in politics, as women tend to lack political ambition (Fox and Lawless 2004, 2010; Lawless and Fox 2005, 2015). Specifically, the findings on the gender gap in the emergence of political candidates in Fox and Lawless's studies (Fox and Lawless 2004, 2010; Lawless and Fox 2005, 2015) suggest that the lack of political ambition explains why women are less likely to run for political seats. As women are reported to have lower self-confidence and fewer aspirations to run for political office, female role models in the political arena may be particularly crucial in increasing women's political ambition, which may, in turn, transform into actual forms of political participation. As enhanced descriptive representation may lead women to see opportunities for success in political action, women may be more likely to engage in politics under the exposure of female political leaders. Thus, increased descriptive representation may lead women to see opportunities for success in political action. 
Furthermore, the positive impact of female legislators on the likelihood of placing women's issues on the agenda as well as their support for womenrelated policies helps explain why increasing representation among women in office might lead to increases in women's political participation. Female legislators have been tied to substantive changes in policies for women (Bratton and Ray 2002; Kathlene 2001; Kittilson 2006, 2008; SchwindtBayer 2010). Women's recognition of the substantive influence of female politicians may lead them to believe that political participation by citizens could also have such a substantive effect. In these circumstances, their feelings of political efficacy are likely to increase (Celis et al. 2008; Childs and Krook 2008; Fox and Lawless 2014; Kittilson 2005) and they will be inspired to increase their own political engagement (Burns, Schlozman, and Verba 2001), suggesting that women legislators have a significant impact on women's political activism through their activities for women.

Finally, it is also likely that when women hold powerful positions in the chamber that the institution itself is transformed by the incorporation of women's viewpoints in a way that fundamentally alters the political institution (Hawkesworth 2003; see, e.g., Borrelli 2002 on the regendering of the executive branch). Such regendering of the institution may create political institutions that are more attractive, and therefore more welcoming, to individual women citizens. Increased representation might lead to changes in institutional norms or practices that are more women friendly. These changes may, for example, lead to different management styles or organizational philosophies that are more welcoming to women (McGlenn and Sarkees 1997). Thus, increasing women's representation may alter the characteristics of the political institution itself.

The mechanisms described here, however, are not specific to representation in national legislatures, although empirical studies of the role model effect on political participation have focused on women in the legislature. Women's representation in other democratic institutions may provide the visibility needed to be a role model for individual citizens; the substantive effect on policy that might inspire political action; and the ability to regender political institutions that might make them more welcoming to women. Indeed, women in political office are only likely to serve as role models or create a substantive effect that inspires action by others to the extent that they are visible enough to be noticed by ordinary citizens in the first place. 
We argue that, in fact, this is as likely to occur when women are in cabinet positions as in legislatures because female cabinet ministers are highly visible. There are a number of examples of cabinet ministers who both achieved visibility in their countries and substantively influenced policy on women's issues. Adriana Delpiano, who has held numerous ministerial positions in Chile, has focused on issues of domestic violence against women. Tanya Plibersek, who also held ministerial positions in Australia, is another example of a high-profile cabinet member who has devoted much attention to women's issues. During her terms, she initiated policies that tackled domestic violence against women and approved abortion drugs. To examine further how women's representation in the cabinet might have a different influence on citizens' political participation, we consider how ministerial representation compares with legislative representation in the next section.

\section{Female Political Leaders in Legislatures and Cabinets}

The research mentioned earlier relies heavily on women's presence in legislatures (Inglehart and Norris 2003; Karp and Banducci 2008; Kittilson 2006; McDonagh 2009; Norris and Lovenduski 1993; Paxton and Kunovich 2003; Schwindt-Bayer 2010; Wolbrecht and Campbell 2007). Nonetheless, we argue that elected ministerial representation is also likely to engender greater political participation. To understand why, we focus on the three distinctions between elected legislative representation and appointed ministerial representation, which might lead descriptive representation in these areas to have divergent implications for women citizens' political participation: the degree to which women citizens are represented, the pathways to the two types of political offices, and the responsibilities that each type of representative assumes (Annesley et al. 2012).

First, while gender inequality in the national legislature is prevalent across democracies, women's descriptive representation in the cabinet does not always mimic their representation in the legislature. Table 1 shows that women, although constituting half of the population, do not hold half of the positions in either parliament or the cabinet. Most, but not all, countries have a higher presence of women in the cabinet than in parliament. Nonetheless, those countries with the highest proportion of women in parliament are not necessarily the ones with the highest proportion of women in the cabinet, suggesting that the proportion of 
Table 1. Presence of women in lower house legislatures and in cabinets among countries in the World Values Survey, 2009

\begin{tabular}{lcccc}
\hline Country & $\begin{array}{c}\text { \# of Female } \\
\text { Ministers }\end{array}$ & $\begin{array}{c}\text { \% Female } \\
\text { Ministers }\end{array}$ & $\begin{array}{c}\text { \# of Female } \\
\text { MPs }\end{array}$ & $\begin{array}{c}\text { \% Female } \\
\text { MPs }\end{array}$ \\
\hline Armenia & 2 & 11 & 12 & 9 \\
Australia & 13 & 42 & 41 & 27 \\
Chile & 9 & 43 & 17 & 14 \\
Colombia & 3 & 23 & 14 & 8 \\
Estonia & 2 & 15 & 23 & 23 \\
Germany & 6 & 40 & 204 & 33 \\
Japan & 2 & 11 & 54 & 11 \\
Mexico & 2 & 11 & 138 & 28 \\
Netherlands & 11 & 39 & 63 & 42 \\
New Zealand & 16 & 31 & 41 & 34 \\
Pakistan & 2 & 5 & 76 & 22 \\
Peru & 6 & 38 & 33 & 28 \\
Poland & 5 & 29 & 92 & 20 \\
Spain & 8 & 47 & 128 & 37 \\
Sweden & 10 & 48 & 162 & 46 \\
Trinidad and Tobago & 7 & 30 & 11 & 27 \\
Turkey & 1 & 7 & 50 & 9 \\
Ukraine & 1 & 5 & 36 & 8 \\
United States of America & 5 & 26 & 73 & 17 \\
Uruguay & 3 & 25 & 14 & 14 \\
\hline
\end{tabular}

Source: IPU (2009) and the cabinet data from Krook and O’Brien (2012) (http://www.dianaobrien.com/).

women in the legislature is not necessarily a proxy for the level of women's representation throughout government. For example, in 2009 in the countries included in the World Values Survey (WVS), the share of women in parliaments ranged from $8 \%$ to $46 \%$ and the share of women in cabinets ranged from $5 \%$ to $48 \%$. Within these countries, however, representation in the cabinet and the parliament was not equal. In Chile, for example, women were well represented in the cabinet in 2009 $(43 \%)$ but not well represented in parliament $(14 \%)$, while in Pakistan, women made up a higher proportion of the parliament $(22 \%)$ than of the cabinet $(5 \%)$.

Second, the eligibility pools for legislators and ministers are also distinctive, affecting the visibility of these two groups of representatives. According to Annesley et al. (2012), there are essentially two ways for women to be elected as ministers. First, elected parliamentarians who belong to the party or parties that constitute the government, with a few exceptions, are eligible for ministerial positions. The process of 
becoming a candidate for a parliamentary seat is already one that requires resources and support from party elites (Fox and Lawless 2010; Norris and Lovenduski 1993). In those systems in which the cabinet is drawn from members of parliament, additional resources and patronage of party elites are required to enter the cabinet. Members of the cabinet are either the leader of their own party or appointed by these party leaders and are usually highly visible within their party organization (Krook and O’Brien 2012; Warwick and Druckman 2006). As a result, they are more likely to be known to the public than the average members of parliament before taking ministerial positions. Second, in some countries, cabinet officials may also come from outside a party's representation in parliament. Much like the members of parliament chosen for these positions, the women chosen from outside parliament for these positions are already highly visible in their countries (Annesley et al. 2012; Annesley and Gains 2010). Consequently, female ministers as a whole are likely to be better known and more visible to citizens than their counterparts who are elected to parliament.

Even when female cabinet ministers are not highly visible prior to their entry into the cabinet, the limited size of most cabinets and the small number of cabinet ministers placed at the head of parts of the bureaucracy increase a woman politician's visibility. For example, Angela Merkel, the current German chancellor, was in her first term in the German Bundestag and had little political experience when she was appointed minister of women and youth (Wiliarty 2008). During the period she served in this position, an intense debate around the creation of a single abortion law for East and West Germany made her an important spokesperson on women's issues. While she served as minister of the environment, large and heavily publicized demonstrations against the transportation of nuclear waste through Germany also raised her visibility. The media attention that Merkel received during her tenure in both offices helped her move from a relatively unknown politician to a leader within the Christian Democratic Union (Steckenrider 2013). We argue that the increased visibility of these previously unknown women that came with their ministerial positions and their success in office likely inspire women to be politically engaged (Atkeson 2003).

Third, the responsibilities of legislators and ministers also vary, although both legislators and ministers create policy, oversee the execution of those policies, and must be responsible to constituents. In the area of policy creation, cabinet members usually have the power to determine the implementation of regulations and often initiate legislation in their 
portfolio area. In contrast, a member of parliament's power to do either of these things is much more circumscribed, although members of parliament may use their individual powers in a wider array of policy areas than a cabinet minister holding a specific portfolio. Consequently, cabinet members' responsibilities in the first two areas are more extensive in terms of the power to influence policy as well as visibility to citizens. An example of this occurred during Michelle Bachelet's term as minister of health in Chile, during which time she introduced a commission to examine ways of reforming the health care system to create more gender equity (Ewig 2008). She also issued a regulation expanding access to emergency contraception that considerably altered the discussion around reproductive rights (Franceschet 2010). Consequently, female ministers have more extensive powers to initiate policies than members of parliament, although these powers are limited to their particular portfolio. Many political decisions are ultimately made and approved by individual cabinet members, while individual legislators are rarely so clearly tied to specific substantive areas.

In sum, women in the cabinet are, on average, likely to have more power to affect policy and greater visibility than their counterparts in the legislature. If the role model effect is based on visibility, on average, cabinet ministers should be more likely to inspire increased political participation than elected members of the national parliament. If the role model effect is influenced by seeing women as political actors that create substantive change, women cabinet members - as high-ranking state officials and as heads of particular parts of the national bureaucracy - should affect citizen participation more than their female counterparts in the legislature. To understand how this affects specific types of political participation, however, we first need to discuss the different ways that citizens participate in the polity.

\section{Variation in the Forms of Political Participation}

In previous explorations of the role model effect, measures of citizens' political participation have varied in a number of ways. Some utilize measures that involve low-cost aspects of behavior such as political interest, political trust, or political knowledge (Karp and Banducci 2008; Kittilson and Schwindt-Bayer 2010; Zetterberg 2009). Others focus on more costly engagement in electoral politics such as voting, working in a campaign, making a campaign contribution, joining a political 
organization, or contacting a government official or party leader (Barnes and Burchard 2012; Burns, Schlozman, and Verba 2001; Desposato and Norrander 2009; Wolbrecht and Campbell 2007). Some scholars have even employed measures of participation that focus on highly costly acts that are not necessarily connected to electoral institutions such as boycotting or demonstrating (Wolbrecht and Campbell 2007). The foregoing discussion of the mechanisms by which women in government positions influence citizen participation suggests the need to consider the specific forms that political participation takes.

Political participation, originally equated with voting, is now better conceptualized as civic engagement. Conceptualizations of civic engagement vary from a range of activities related to electoral politics (Dalton 2008) to feminist definitions that recognize informal activities in the private sphere (see, e.g., Lister 2003, 145-47). Although we are constrained by the use of existing surveys, we measure political action as broadly as possible by including both conventional (electoral politics related) and unconventional forms of political action - defined as boycotts and strikes - as well as activities that lie between the two. Particularly, we consider petition signing and peaceful demonstrations as borderline actions because they can be incorporated into both electoral politics and activities outside of or opposed to electoral politics. Table 2 illustrates the distinctions we see between these different forms of behavior position. As each specific form of political involvement varies by its type of influence, scope of outcome, conflict level, initiative required, cooperation with others, and connections with electoral institutions (Dalton 2008; Verba, Nie, and Kim 1978), we expect the effect of women's presence in political institutions on individuals' use of each form of political action to differ.

Table 2. Mapping the difficulty and cost level and electoral connections of various forms of political participation

Least Difficult Most Difficult

Most Connected with

Least Connected with

Electoral Institutions

Electoral Institutions

\begin{tabular}{|c|c|c|c|}
\hline $\begin{array}{l}\text { Conventional action } \\
\text { (voting + party } \\
\text { membership) }\end{array}$ & $\begin{array}{l}\text { Petition } \\
\text { signing }\end{array}$ & $\begin{array}{l}\text { Peaceful } \\
\quad \text { demonstration }\end{array}$ & $\begin{array}{l}\text { Unconventional } \\
\text { action } \\
\text { (boycotts + strikes) }\end{array}$ \\
\hline
\end{tabular}


Conventional electoral political action, such as voting and being a member of a political party, is closely related to electoral institutions. While both members of parliament and members of government are tied to electoral politics, ministers are generally more visible, making them more likely to influence women citizens' activities. Moreover, because ministers are highly engaged in electoral politics - both through their own selection and as part of their jobs - we expect that an increasing the proportion of female ministers encourages women to participate in conventional politics, specifically, voting and obtaining political party membership.

$H_{1}$ : Holding all else constant, as the proportion of women in the cabinet increases, so does the likelihood of women engaging in conventional electoral political action (voting and obtaining political party membership).

Petition signing is another form of political participation that allows individuals to convey their preferences to elected representatives. Although petitions need not be part of normal electoral politics petition signing has increasingly become connected to electoral institutions over the last few decades. ${ }^{1}$ While petition signing might also be utilized to target industries and corporations, reducing its connection with electoral institutions, it still serves as a means for individuals to communicate with elected leaders. Particularly, petition signing allows for very clear messages to be conveyed as each petition is aimed at a specific issue or policy. Moreover, the difficulty and costs associated with petitioning have decreased in recent years. Online activism, which has increased dramatically in recent years, has made petition signing a relatively effortless endeavor, enhancing individuals' participation in petition signing (Earl and Kimport 2009; Earl et al. 2010; Kahne, Middaugh, and Allen 2014; Maguth 2012). To the extent that women in the cabinet increase female citizens' efficacy and sense of representation through policy making, we expect women to be encouraged to sign petitions to express their concerns as the presence of female ministers rises.

$\mathrm{H}_{2}$ : All else being equal, the higher the proportion of female ministers, the more likely it is that women will be willing to sign petitions.

The linkage between lawful demonstrations and electoral institutions, however, is not as clear. We suspect that there are multiple ways that women's presence in the cabinet might influence this form of political

1. Dalton (2008) classified petition signing as unconventional political action. 
participation. Peaceful demonstrations generally are understood as an unconventional form of action requiring more effort, necessitating a higher degree of cooperation (e.g., with other demonstrators) and encompassing more risks to the participant (Dalton 2008). Demonstration also traditionally serves as a "political resource of minorities and repressed groups" that can be utilized to express political preferences when groups are excluded from the political process (Dalton 2008, 63). However, when women are present in official political institutions such as the cabinet, female citizens might feel that they can utilize conventional outlets, such as voting, to express their opinion. If true, demonstrations are not likely to increase when more women are in the cabinet. Moreover, given the policy powers of female ministers, women citizens may feel that increased descriptive representation is accompanied by increases in substantive representation in policy as well. This might lead female citizens to believe they do not need to engage in demonstrations against the government, suggesting that the presence of female ministers might even reduce women's participation in peaceful demonstrations. This leads us to hypothesize,

$\mathrm{H}_{3 a}$ : All else being equal, an increase in women's representation in the cabinet leads to a decrease or no change in the level of women's attendance in peaceful demonstration.

On the other hand, despite the great demand on resources required for organizing demonstrations, protest has become more common over the last few decades. Even Dalton now defines demonstrations as an "extension of conventional political action" (2008, 91), departing from his previous definition in 1988. Indeed, in the United States, female cabinet ministers have even participated in demonstrations (Banaszak 2010). To the extent that protest is now a normal political activity through which individuals express their political preference and establish connections with electoral institutions, we also expect that female ministers to serve as role models for this form of women's participation.

$H_{3 b}$ : All else being equal, the higher the proportion of female ministers, the more willing women will be to participate in peaceful demonstrations.

We argue that boycotting or joining a strike are different from peacefully demonstrating because they involve more costly, potentially illegal, and occasionally violent actions (Dahl and Stattin 2014; Dalton 2008; Wolfsfeld et al. 1994). This form of engagement requires more effort and coordination than peaceful demonstration and is rarely used to engage in 
electoral politics. The potential for harm to the participants is increased because governments are more likely to respond negatively to this behavior. Additionally, strikes and boycotts are usually disconnected from the electoral institutions where cabinet ministers' primary responsibilities and activities lie. Boycotts and strikes usually target economic institutions, such as corporations or employers, which also are more removed from the electoral institutions, where female ministers serve as role models. For this reason, we hypothesize,

$\mathrm{H}_{4}$ : Holding all other factors constant, increasing women's ministerial representation does not lead to an increase in women's willingness to engage in unconventional political action.

\section{DATA AND METHODOLOGY}

We analyze how female ministers shape women's civic engagement by analyzing individual indicators of women's political participation using Wave 6 of the World Values Survey, which was fielded in 2010 and released in 2014. ${ }^{2}$ These survey data are combined with national-level context measures including an indicator of women's political representation in the cabinet in 2009 taken from Krook and O'Brien's data (2012). All national-level context variables are taken from 2009, one year prior to the fielding of the WVS, unless otherwise indicated. Our dataset includes citizen surveys and national-level data from 20 democracies: Armenia, Australia, Chile, Colombia, Estonia, Germany, Japan, Mexico, the Netherlands, Pakistan, Peru, Poland, Spain, Sweden, Trinidad and Tobago, Turkey, Ukraine, the United States of America, Uruguay, and New Zealand. ${ }^{3}$ Next, we describe the specific measures in greater detail.

\section{Dependent Variable}

Our primary interest is how women engage in multiple forms of political behavior. Specifically, we use four dependent variables: conventional action, petition signing, protest participation, and unconventional action. Our tests of significance indicate that a gender gap between men and

2. Data and documentation can be found at http://www.worldvaluessurvey.org/wvs.jsp.

3. The nature of the survey questionnaire is such that we cannot know the specific demonstrations in which the respondents participated. 
women exists across all forms of participation $(p<.05)$. Men participate significantly more than women in voting and obtaining party membership, petition signing, attending peaceful demonstrations, and boycotting and joining strikes.

Participation in conventional electoral politics - our first measure of political behavior - is measured through two types of electoral activity, specifically, how frequently respondents vote and their membership in political parties. Respondents are asked about their frequency of voting, where $1=$ never, 2 = usually, and $3=$ always. Respondents are also asked whether they are an active member, an inactive member, or not a member of a political party on a scale ranging from $1=$ not a member to $3=$ active member. We create an index of conventional action by averaging the two measures, that is, by combining voting behavior and party membership. Second, we measure respondents' propensity to sign petitions and to participate in peaceful demonstrations. ${ }^{4}$ Both measures are based on a single question. Respondents are asked whether they have ever signed a petition or attended a peaceful demonstration. Both measures are on a scale of $1=$ would never do to $3=$ have done.

To operationalize unconventional political participation, we create an index that combines survey questions about each respondent's willingness to join strikes and participate in boycotts. The WVS does not explicitly reference specific boycotts and/or strikes in its questionnaires; therefore, we assume that the respondents are indicating their overall participation in these two types of activity based on a general understanding of boycotts and strikes. Boycotts are assumed to be seen as an act to withdraw support for an organization or an institution by removing ties or relations. Strikes are assumed to be understood as work stoppages that are used against employers to gain bargaining power. Our index of unconventional participation is created by taking the average of responses to questions concerning the respondents' propensity to join boycotts and strikes. In both cases, the possible responses to the questions

4. Given the nature of the WVS, which asks general questions about the respondents' propensity to participate in general forms of petition signing and peaceful demonstrations, we are unable to identify the specific details of these actions. In other words, we know whether respondents participated and (occasionally) the frequency of their engagement, but we do not know the types of petitions that they have signed or the targets or goals of the demonstrations in which they participated. Current cross-national surveys are insufficient to address how women's political representation influences the focus of women's petition signing or demonstrating. Moreover, we cannot know how the subjects, goals, and missions of women's petitioning or protesting differ. Hence, examining the gaps in participation on political actions that have varying targets and goals is beyond the ability of this study. Future data collection and research are necessary to address these questions. 
Table 3. Descriptive statistics of all national-level and individual-level variables in all countries

\begin{tabular}{lrrrrr}
\hline Variable & N & Mean & SD & Min. & Max. \\
\hline Female & 28,955 & 0.53 & 0.50 & 0 & 1 \\
Age & 28,938 & 46.49 & 17.68 & 17 & 98 \\
Education & 28,359 & 5.95 & 2.28 & 1 & 9 \\
Employed & 29,730 & 0.53 & 0.50 & 0 & 1 \\
Married & 28,804 & 0.52 & 0.50 & 0 & 1 \\
Political knowledge & 27,019 & 3.46 & 0.89 & 1 & 5 \\
Electoral system & 28.960 & 1.30 & 0.77 & 0 & 2 \\
Female labor participation & 28.960 & 42.39 & 6.86 & 20.31 & 49.62 \\
GDP per capita & 28,960 & 22.93 & 17.37 & 0.95 & 48.00 \\
Suffrage & 28,960 & 78.39 & 15.23 & 54 & 107 \\
Gender ideology & 28,960 & 2.39 & 0.22 & 1.68 & 2.61 \\
Gender inequality index & 28,960 & 0.29 & 0.16 & 0.07 & 0.61 \\
\% left party & 20,939 & 36.18 & 29.95 & 0 & 94.69 \\
Female head of state & 28,960 & 0.16 & 0.36 & 0 & 1 \\
Proportion of women in parliament & 28,960 & 0.23 & 0.11 & 0.08 & 0.46 \\
Proportion of women in cabinet & 28,960 & 0.25 & 0.14 & 0.05 & 0.48 \\
Female * Proportion of women in cabinet & 28,954 & 0.13 & 0.16 & 0 & 0.48 \\
Conventional participation & 28,392 & 1.85 & 0.42 & 1 & 3 \\
Petition signing & 27,892 & 1.99 & 0.82 & 1 & 3 \\
Demonstration participation & 27,696 & 1.69 & 0.71 & 1 & 3 \\
Unconventional participation & 27,963 & 1.50 & 0.57 & 1 & 3 \\
\hline
\end{tabular}

range from $1=$ would never do to $3=$ have done. Table 3 reports the descriptive statistics on these dependent variables as well as all independent variables. All four of the dependent variables analyzed here range in value from 1 to 3 , with 3 always indicating more participation.

\section{National-Level Variables}

Our main variable of interest is the proportion of female ministers in the cabinet, which we take from Krook and O'Brien's cabinet data collected in 2009, one year prior to the fielding of the WVS. ${ }^{5}$ The proportion, with a scale of 0 to 1 , indicates the proportion of all ministers in the cabinet who are female. Women's representation in the cabinet varies considerably, ranging from 5\% of women in Pakistan and Ukraine to $48 \%$ in Sweden. In order to directly test and compare the effects of

5. To ensure that the effects of women's presence politics are easily interpreted, we use the proportion of women's representation instead of the percentage of women in either legislature or cabinet. This variable ranges from 0 to 1 . 
female ministers with those of female legislators, we also include a measure of the proportion of women in the legislature, obtained from the InterParliamentary Union's 2009 report of the percentage of women in lower houses - the same year that Krook and O'Brien's cabinet data were collected. We then adjust this variable into a proportion, on a scale of 0 to 1 , in order to maintain consistency with the measure of female ministers. We control for women's presence in parliament, particularly because one might expect that representation in the cabinet would be affected by the presence of women in legislature (Davis 1997).

In choosing the other covariates, we generally try to model our analysis after Wolbrecht and Campbell (2007), employing the same national-level controls in our analysis. We do not include dummies for the Scandinavian countries and the former communist states in Eastern Europe because variation is insufficient; only Poland and Sweden fall under these categories. Nonetheless, we realize the importance of cultural acceptance toward women as political executives and suspect that having a female prime minister or president might also carry role model effects apart from the gender diversity of the cabinet. Therefore, we control for the gender of the head of the state in 2009. Chile, Germany, and Ukraine are the three cases in our dataset that have either a female prime minister or female president during 2009.

We anticipate that cultural acceptance of women in politics is also important (Caul 2001). Because the norm of women in politics (and hence as political representatives) develops over time, we measure the number of years up to 2009 that a country had women's suffrage. We collect data on the year that women's suffrage was passed in each country and subtract that year from 2009 to reach the number of years that women have experienced voting rights. As women who participate in the labor force are likely to become leaders (Moore and Shackman 1996; Paxton 1997; Paxton and Kunovich 2003), we also include the percentage of women in the labor force (female labor force), gathered from the World Bank (2009), that examines the percentage of women in the population age 15 and older that is economically active in 2009.

We also control for gender inequality using the United Nations Gender Development Index, as gender inequality might be correlated with women's representation and participation in politics. The Gender Inequality Index reflects gender inequality in three aspects: reproductive health, empowerment, and the labor market. The data are compiled from various sources, including the maternal mortality ratio from the United Nations Children's Emergency Fund and educational attainment 
from the United Nations Educational, Scientific and Cultural Organization's Institute for Statistics. The index closest and prior to the World Values Survey fielded in 2010, however, is only available in 2005. Thus, we use this measure as our national-level indicator of the state of women's disadvantages. ${ }^{6}$

As Inglehart and Norris (2003) suggest that development and cultural transformation play an important role in shaping gender attitudes, we create a variable to represent national gender ideology by taking the national average of an index of two questions that ask respondents how they perceive women's roles. Participants in the survey are asked to respond on a scale of $1=$ agree strongly to $4=$ strongly disagree to the following two statements: (1) "On the whole, men make better political leaders than women do," and (2) "A university education is more important for a boy than for a girl." 7 These questions resemble the gender ideology questions in the three surveys - Civic Education Study (1999-2000), European Education Study (1999-2002), and European Social Survey (2004) - used in Wolbrecht and Campbell's (2007) study.

In addition to gender-related measures, we also control for other national-level variables that might exert influence on the proportion of female cabinet members. First, the type of electoral system is found to influence the level of descriptive representation of women (Gallagher and Mitchell 2005; Lijphart 2012). Particularly, proportional representation systems are found to be more women friendly, as women are more likely to be represented in party lists (Bogdanor 1992; Gallagher and Mitchell 2005; Matland and Studlar 1996). Therefore, we use Golder's (2005) measure of legislative type to indicate each country's electoral system. Countries are recoded as 0 for having a majoritarian system, 1 for having a mixed system, and 2 for having a proportional representation system. Additionally, we include each country's gross domestic product (GDP) per capita in 2009, collected from the World Bank (2009), as a control because a country's economic development

6. While this indicator is collected in 2005, which is different from the time period that the other national-level variables are collected, the indicator does not change much in the course of four years (between 2005 and 2009). Countries that have a low Gender Inequality Index remain low, while the countries that have a high Gender Inequality Index remain high. As the variation is consistent over time, this should not influence our analysis.

7. Although Paxton and Kunovich (2003) suggest there are other questions that could potentially be included to gauge gender attitudes, as, we chose questions that relate to women's roles as political leaders rather than questions about the private sphere, such as whether being a housewife or a working mother is equally fulfilling and rewarding. 
may influence the resources available for individuals to participate in political activity (Abramson and Inglehart 1995; Inglehart 1990, 1997).

\section{Individual-Level Variables}

On the individual level, we also utilize similar variables to Wolbrecht and Campbell's (2007) models. ${ }^{8}$ Important for the analysis that follows is the respondents' sex $($ female $=1)$. Our hypotheses revolve around the influence of female ministers on women's political participation, so we interact female with the proportion of female ministers. We control for the educational background of the respondent to indicate a person's socioeconomic status. Respondents are asked about the highest-level of education they have attained, ranging from $1=$ no formal education to $9=$ university-level education, with degree. We also control for the respondents' marital status, as personal biography has been found as an important factor in whether and how an individual behaves politically (McAdam 1986, 1992). Additionally, we control for whether the respondent is employed, as employment and networks derived from the workplace increase the likelihood that individuals will be recruited into political activity (Schlozman, Burns, and Verba 1999; Welch 1977). Employed respondents are coded 1. Finally, we control for the respondent's age.

As the respondents are sampled within different countries, we utilize a two-level model, employing multilevel modeling techniques to account for the clustered nature of the data by allowing the intercept to vary randomly across nations (Raudenbush and Bryk 2002). We also employ a cross-level interaction term - whether the respondent is female times the proportion of female ministers - to examine the role model effect on women. Our model is as follows:

$$
\begin{aligned}
Y_{i j}= & \beta_{0}+\beta_{1}\left(\text { Female }_{i}\right)+\beta_{2}\left(\text { Age }_{i}\right)+\beta_{3}\left(\text { Education }_{i}\right)+\beta_{4}\left(\text { Employed }_{i}\right) \\
& +\beta_{5}\left(\text { Married }_{i}\right)+e_{i}
\end{aligned}
$$

8. We are unable to include the number of books individuals have at home because this question is not asked in the WVS. Because we employ a multilevel approach, omitted individual level variables do not alter the effects of the national-level indicators, which are of primary interest. However, we do note that one's political knowledge might also shape how aware a respondent is of the proportion of women cabinet ministers in their countries. Thus, we replicate our analysis including participants' political knowledge, which is measured by the amount of news consumption respondents have. This necessitates leaving Morocco out of our dataset. See Table 6 in the online appendix for detailed results. 


$$
\begin{aligned}
& \beta_{0}=\gamma_{00}+\gamma_{01}\left(\text { Female Ministers }_{j}\right)+\gamma_{02}\left(\text { Female MPs }_{j}\right) \\
& +\gamma_{03}\left({\text { Female Head of } \left.\text { State }_{j}\right)}+\gamma_{04}\left(\text { Female Labor Force }_{j}\right)\right. \\
& +\gamma_{05}\left(\text { Suffrage }_{j}\right)+\gamma_{06}\left(\text { Gender Ideolog }_{j}\right) \\
& +\gamma_{07}\left(\text { Electoral system }_{j}\right)+\gamma_{08}(\text { Per Capita GDP } j)+\mu_{0}
\end{aligned}
$$

Our cross-level interaction in the model between the sex of the respondent and the proportion of women in the cabinet is introduced as following:

$$
\beta_{1}=\gamma_{10}+\gamma_{11}(\text { Female Ministers })+\mu_{1}
$$

\section{RESULTS AND DISCUSSION}

Our modeling strategy follows our categorization of political participation into multiple modes. Table 4 presents the multilevel models for four dependent variables, each of which represents a different form of political participation. Partial models and several robustness checks are provided in the online appendix. We start by noting that although the previous literature found that women's legislative representation shapes women's political activity (Barnes and Buchard 2012; Norris and Krook 2009; Wolbrecht and Campbell 2007), the variable representing women's legislative representation is insignificant for all four measures of participation. We expect that the reason for the different findings is that we control for the proportion of women in the cabinet. Because of the potentially higher visibility of female ministers, we expected that female ministers would have a greater impact on women's political participation. When both variables are included in the model, women's legislative representation does not have a significant effect on any of the forms of political participation. ${ }^{9}$

Our hypotheses suggest that the effect of women's representation in the cabinet on women citizens' political participation differs depending on the specific type of political participation, with types varying in costs in time

9. Table 7 in the online appendix shows that without the interaction term, women in the legislatures do not influence individuals' engagement in conventional politics, petition signing, and unconventional politics. Women in parliament are only found to affect individuals' participation in peaceful demonstrations. On the contrary, women in the cabinet are shown to affect individuals' participation in petition-signing and unconventional political actions when the interaction term is excluded. 
Table 4. Influence of proportion of women in the cabinet on various forms of women's political participation

\begin{tabular}{|c|c|c|c|c|}
\hline Models & $\begin{array}{c}(1) \\
\text { Conventional } \\
\text { participation }\end{array}$ & $\begin{array}{c}(2) \\
\text { Petition } \\
\text { Signing }\end{array}$ & $\begin{array}{c}(3) \\
\text { Demonstration }\end{array}$ & $\begin{array}{c}\text { (4) } \\
\text { Unconventional } \\
\text { participation }\end{array}$ \\
\hline \multicolumn{5}{|l|}{ Individual-Level } \\
\hline Female $(=1)$ & 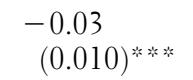 & $\begin{array}{l}-0.03 * \\
(0.017)\end{array}$ & 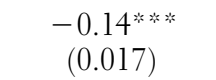 & $\begin{array}{c}-0.09 \text { 米称 } \\
(0.013)\end{array}$ \\
\hline Age & 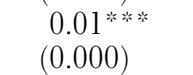 & $\begin{array}{l}0.00 \text { 祡和 } \\
(0.000)\end{array}$ & $\begin{array}{l}0.000 \text { ** } \\
(0.000)\end{array}$ & $\begin{array}{c}-0.00 \text { 祡的 } \\
(0.000)\end{array}$ \\
\hline Education & $\begin{array}{l}0.02 \text { **** } \\
(0.001)\end{array}$ & 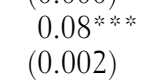 & 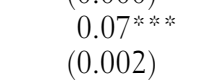 & $\begin{array}{l}0.05^{\text {米将 }} \\
(0.002)\end{array}$ \\
\hline Employed $(=1)$ & 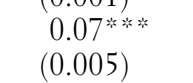 & 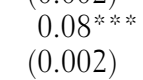 & 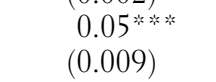 & 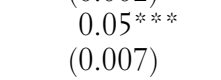 \\
\hline Married & $\begin{array}{l}0.07^{\text {等的 }} \\
(0.005)\end{array}$ & 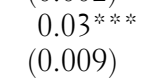 & $\begin{array}{c}-0.01 \\
(0.009)\end{array}$ & 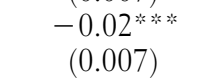 \\
\hline \multicolumn{5}{|l|}{ National-Level } \\
\hline Electoral system & $\begin{array}{l}-0.01 \\
(0.027)\end{array}$ & $\begin{array}{r}-0.17^{\text {***is }} \\
(0.061)\end{array}$ & 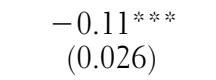 & $\begin{array}{l}-0.07^{*} \\
(0.031)\end{array}$ \\
\hline $\begin{array}{l}\text { Female labor } \\
\text { participation }\end{array}$ & 0.00 & -0.01 & $-0.01^{\text {* }}$ & $-0.01 *$ \\
\hline & $(0.004)$ & $(0.010)$ & $(0.004)$ & $(0.005)$ \\
\hline GDP per capita & $\begin{array}{c}0.00 \\
(0.002)\end{array}$ & $\begin{array}{c}0.01 \\
(0.005)\end{array}$ & $\begin{array}{c}-0.00 \\
(0.002)\end{array}$ & $\begin{array}{c}0.00 * \\
(0.003)\end{array}$ \\
\hline Suffrage (years) & $\begin{array}{l}0.00 \\
(0.002)\end{array}$ & $\begin{array}{l}0.00 \\
(0.004)\end{array}$ & $\begin{array}{l}-0.00 \\
(0.002)\end{array}$ & $\begin{array}{c}0.00 \\
(0.002)\end{array}$ \\
\hline Gender ideology & $\begin{array}{c}0.15 \\
(0.142)\end{array}$ & $\begin{array}{c}0.46 \\
(0.326)\end{array}$ & $\begin{array}{c}0.45^{\text {* }} \\
(0.140)\end{array}$ & $\begin{array}{l}0.15 \\
(0.164)\end{array}$ \\
\hline $\begin{array}{l}\text { Gender } \\
\text { inequality index }\end{array}$ & 0.72 ; & -0.09 & -0.25 & 0.20 \\
\hline & $(0.292)$ & $(0.670)$ & $(0.288)$ & $(0.338)$ \\
\hline $\begin{array}{l}\text { Female head of } \\
\text { state }(=1)\end{array}$ & -0.07 & $-0.19 \%$ & 0.01 & -0.08 \\
\hline & $(0.049)$ & $(0.670)$ & $(0.002)$ & $(0.057)$ \\
\hline $\begin{array}{l}\text { Prop. women in } \\
\text { parliament }\end{array}$ & -0.05 & 0.18 & 0.33 & 0.39 \\
\hline & $(0.237)$ & $(0.543)$ & $(0.234)$ & $(0.274)$ \\
\hline $\begin{array}{l}\text { Prop women in } \\
\text { cabinet }\end{array}$ & $\begin{array}{l}0.29 \\
(0.203)\end{array}$ & $\begin{array}{l}0.79 * * \\
(0.465)\end{array}$ & 0.74 的的的 & $\begin{array}{l}0.74 \text { 次 } \\
(0.235)\end{array}$ \\
\hline $\begin{array}{l}\text { Female }{ }^{*} \text { women } \\
\text { in cabinet }\end{array}$ & 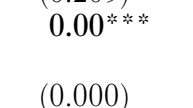 & $0.11^{*}$ & 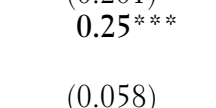 & $(0.044)$ \\
\hline Constant & $\begin{array}{l}0.52 \\
(0.336)\end{array}$ & $\begin{array}{l}0.50 \\
(0.770)\end{array}$ & $\begin{array}{l}0.84 \\
(0.330)\end{array}$ & 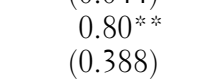 \\
\hline
\end{tabular}


Table 4. Continued

\begin{tabular}{|c|c|c|c|c|}
\hline Models & $\begin{array}{c}(1) \\
\text { Conventional } \\
\text { participation }\end{array}$ & $\begin{array}{c}(2) \\
\text { Petition } \\
\text { Signing }\end{array}$ & $\begin{array}{c}(3) \\
\text { Demonstration }\end{array}$ & $\begin{array}{c}\text { (4) } \\
\text { Unconventional } \\
\text { participation }\end{array}$ \\
\hline Observations & 27,593 & 27,083 & 26,911 & 27,173 \\
\hline Number of groups & 20 & 20 & 20 & 20 \\
\hline
\end{tabular}

Notes: Robust standard errors in parentheses. ${ }^{*} p<.10$; ${ }^{* * *} p<.05$; $* * * * 0.01$.

and effort, ease of access and collaboration, and connections to electoral institutions. As expected, the results in Table 4 show that the effect of female ministers on women's involvement in politics differs depending on the type of participation. The cross-level interaction of being female with the proportion of women in the cabinet is the variable which captures this effect. This variable is significant and in the expected direction for conventional participation, petition signing, and participation in demonstrations but not for unconventional participation. When female ministers are present, women partake more in political actions that are low in cost or closely connected to electoral institutions but not in strikes or boycotts - types of participation that are both more costly to participate in and less connected to electoral politics.

We have two conflicting hypotheses about the effects of female ministers on women's willingness to engage in peaceful demonstrations. On the one hand, we expect female citizens to no longer need unconventional outlets to express their opinions when women serve as ministers. On the other hand, we hypothesize that as peaceful demonstrations become more accepted, their connection to electoral institutions increases, strengthening the role model effect of female cabinet members. Our analysis confirms that the role model effect is strong for participation in demonstrations. The presence of women in the cabinet has a significant positive impact on women's willingness to protest peacefully.

While we find female ministers to be role models for women to partake in actions that are low (and lower) in cost and related to electoral institutions in which female ministers are engaged, we also find that they have less of an impact on women's behavior that carries great risk. Model 4 illustrates support for our hypothesis $\left(\boldsymbol{H}_{4}\right)$ that women's representation in ministerial positions will have no effect on women's unconventional, risky protest behavior. The coefficient for the interaction of female with the proportion of women in the parliament is insignificant $(p>.10)$. 
We do not find this surprising, as boycotting and joining strikes tend to be confrontational and illegal; it is rare to see female ministers partaking in such controversial actions. Consequently, women in the cabinet are not likely to serve as role models to other women to engage in this type of behavior. In sum, $\boldsymbol{H}_{1}, \boldsymbol{H}_{2}, \boldsymbol{H}_{3 b}$, and $\boldsymbol{H}_{4}$ are supported, while $\boldsymbol{H}_{3 \boldsymbol{a}}$ is rejected.

While we had no hypotheses about the control variables, we note that the individual-level variables are in the expected direction. Education and employment increase all types of women's political participation, while the effects of marriage and age vary depending on the type of participation, with older and married people less likely to participate in unconventional participation. Most of the national-level variables do not consistently reach statistical significance. In addition to the proportion of women in parliament and the cross-level interaction, only electoral system achieves significance across a number of models. While electoral systems had no effect on conventional participation, women are significantly less likely to engage in petition signing, demonstrations, strikes, or boycotts in countries with proportional representation systems.

To better understand the strength of the effect that women cabinet members have on the various forms of women's political participation, Figures 1, 2, and 3 illustrate the strength of the role model effects from the analyses in Models $1-3$ in Table $4 .{ }^{10}$ The figures are generated in marginsplot, which graphs the results from estimated margins, illustrating the predicted values for female and male respondents' participation in conventional politics, petition signing, and peaceful demonstrations across different proportions of women in the cabinet in order to help understand the substantive effects of our interaction term. ${ }^{11}$

Figure 1 shows that when $5 \%$ of the cabinet is made up of women, men are, on average, 0.04 point higher than women on our measure of conventional political participation. However, the gender gap begins to decrease and women are increasingly more likely to engage in conventional political action as the presence of female ministers rises. Female citizens' likelihood of voting and becoming members of political parties is essentially equal to men's when cabinets are $48 \%$ women, which is the highest level of women's representation in our sample of

10. We do not create a figure for unconventional participation since the variable of interest shows no effect in this case.

11. All other variables are held at their mean values. 


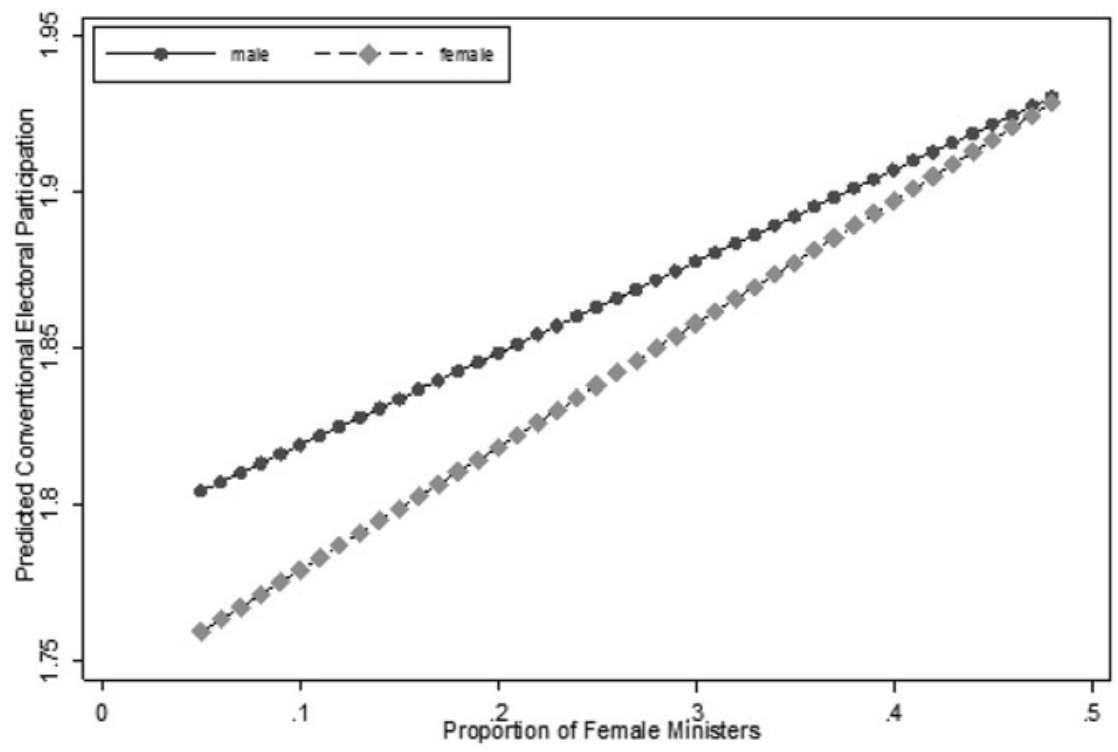

FiguRE 1. Effect of the proportion of female cabinet ministers on women's and men's conventional political participation.

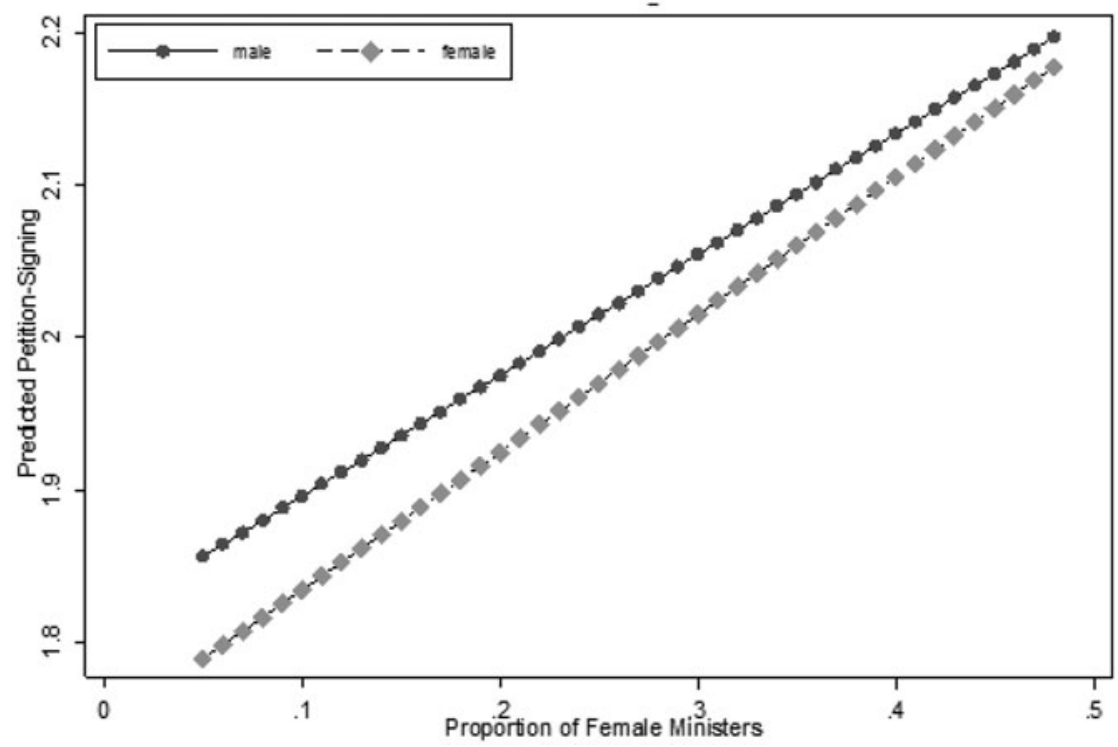

FIGURE 2. Effect of the proportion of female cabinet ministers on women's and men's participation in petition signing. 


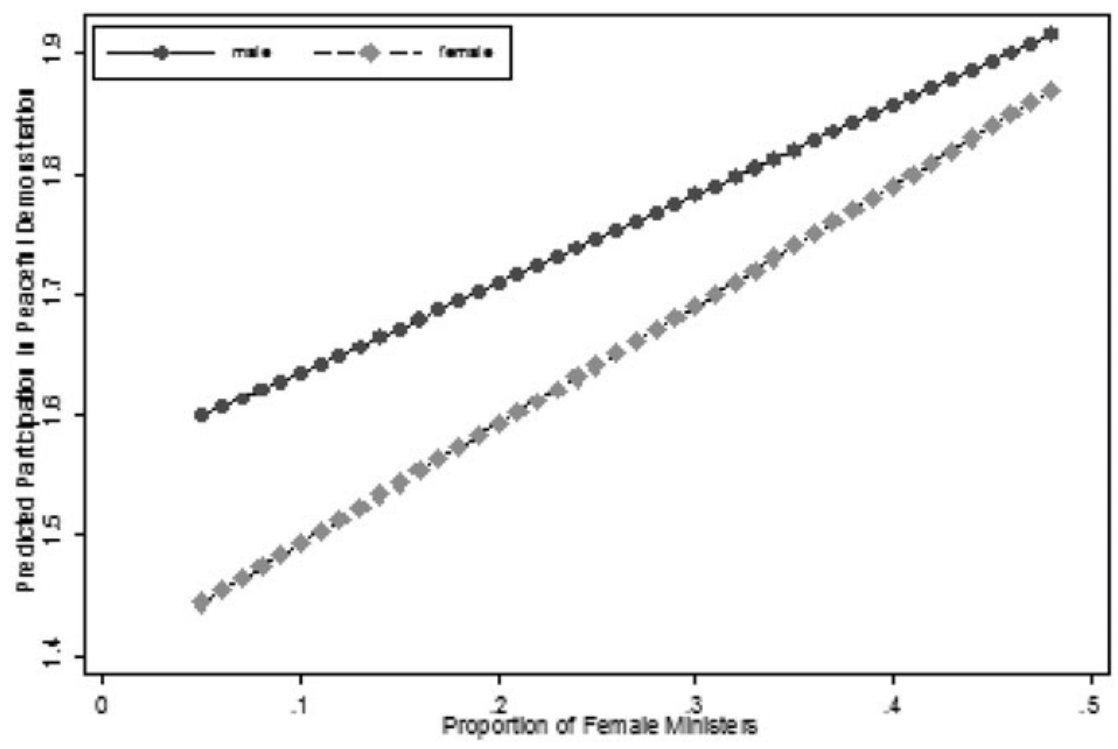

FIgURE 3. Effect of the proportion of female cabinet ministers on women's and men's participation in demonstration.

countries. Most importantly, women's propensity to vote or obtain party membership increases 0.16 point on our three-point index - or almost 0.4 standard deviation - as women's ministerial representation rises from 0.05 to 0.48 . Thus, there is evidence that female ministers serve as role models in inspiring women to engage in conventional politics.

Figure 2 illustrates that men are, on average, more likely to sign petitions than women. When the cabinet is made up of $5 \%$ women, men are 0.07 point on the three-point scale more likely to claim that they have signed petitions. The gap between women's and men's propensities for petition signing continues to narrow as women's representation in the cabinet increases. However, women's willingness to say that they have signed petitions remains less than men's even where the proportion of women in the cabinet reaches the maximum level (0.48) among the countries included in our sample, although when women reach the maximum in the cabinet, the difference between men and women is slight (0.02 point on our three-point scale). Women's propensity to sign petition increases 0.39 point - or 0.48 standard deviation - as the proportion of women in the cabinet rises from 0.05 to 0.48 . This result suggests that women's presence in the cabinet increases female citizens' willingness to sign petitions. 
Even greater differences between men and women's political participation exist on the willingness the engage in peaceful protest. Figure 3 shows that when $5 \%$ of the cabinet ministers are women, men are predicted to attend peaceful demonstrations 0.15 point more on average than women. The gender gap narrows as the proportion of female cabinet ministers rises. When female cabinet members' presence reaches $48 \%$, men are still more likely to attend peaceful demonstrations than women, but only about 0.05 point higher than the average propensity of women. Women's predicted probability to demonstrate increases 0.43 point - or more than 0.6 standard deviation - as the proportion of women in the cabinet rises from 0.05 to 0.48 . Figure 3 suggests that women ministers influence women's attendance at demonstrations. Given our conflicting hypotheses about demonstrating, we argue that this finding suggests that peacefully demonstrating is a form of political participation that is closer in cost and connection to "normal" political participation than it is difficult and unconventional in nature.

Together, although the effects are not large, the figures suggest that as political action becomes more risky, more costly, more conflictual, less connected to electoral institutions, and requires more collective effort, the gap between men and women increases and is not completely ameliorated by the presence of women as ministers. Even when women's representation in the cabinet almost reaches parity with men, gender gaps in participation persist. Gender differences are more likely to disappear if the form of political activity is more connected to conventional politics, such as voting and becoming political party members, than when it consists of actions less connected to electoral activity, such as protesting or signing petitions. For strikes and boycotts, which are far removed from electoral institutions, women's representation in the cabinet does not affect women's participation.

\section{CONCLUSION}

This project makes several contributions to our understanding of individuals' civic engagement and the role that representation plays in encouraging it. First, while the importance of women serving in the legislature has been examined in previous studies, how female ministers might serve as role models has traditionally been underexplored. This article fills the gap in extant studies by theorizing the differences between women's representation in the cabinet and in the legislature 
and examining how those two forms of women's representation influence citizens' political activity. Current findings show that women legislators act as role models in inspiring women to run for office, expressing political interest, engaging in political discussions, and participating in political activity (Atkeson 2003; Fox and Lawless 2014; Wolbrecht and Campbell 2007). We find that women ministers also have similar role model effects in encouraging women to engage in politics. While our findings for female cabinet members mirror those for female legislators, our results indicate that women's ministerial representation plays a more significant role than that of their counterparts in the legislature. Nonetheless, women's representation in the cabinet is an understudied area of the literature on women's representation. Moreover, our study cannot speak to the role that women in other places in politics, such as women bureaucrats or women judges, play in influencing women citizens. We do not yet know to what extent women citizens might look to these other political institutions for role models.

Second, we focus on analyzing differences among multiple modes of political participation, which we categorize based on the costs, risks, and relationship to electoral institutions. The role model effect for female cabinet members varies depending on whether we examine on women's participation as voters and party members, petition signers, peaceful demonstrators, or participants in strikes and boycotts. Female ministers are found to have a significant impact on behaviors targeted at electoral institutions and that are low in cost. That is, the role model effect occurs mostly when female ministers inspire women to participate in ways that most resemble the behavior of female ministers. As female ministers work within and also might be seen as the embodiment of electoral institutions, they appear to encourage women to seek similar outlets to express their political opinion (e.g., through voting, joining parties, and even signing petitions and demonstrating). Our analysis further illustrates that women have different responses when seeing women in cabinet, depending on the costs, risks, and ease of access of each type of participation. Few studies differentiate political actions along these dimensions but our results suggest that the causes of different types of political behavior are likely to vary depending on the role that costs, risks and connection to electoral politics play in the causal mechanisms. All this suggests that future explorations of political behavior should incorporate these factors into their analysis.

The fact that the effect of women's ministerial representation differs depending on the form of participation implies that there may be limits 
to the role model effect. The measures we use to operationalize political participation are still conventional. Other mechanisms of political action exist at various levels, such as organizing communities, running for office, donating money to candidates, occupying, writing on blogs, and mobilizing on social media sites. Yet most current research and our study are unable to address these untraditional and informal notions of participation because of the limitations of existing cross-national public opinion data. Extending the survey instruments to include these additional forms of participation is necessary to examine the role that women politicians may play in influencing these other forms of political participation. This question is particularly important because women's political activity is often constrained by their biographical availability, such as time, domestic, and work commitments, suggesting that women may be more active in less conventional forms of political participation. Not only does the lack of data on these untraditional and informal types of participation miss major arenas in which women may be politically active, but if women are more likely to engage in such activities, it may give an erroneous impression that women's participation in politics is unequal to men's (Lister 2003).

Additionally, the inspirational effect lessens when women are faced with participation that requires more effort and sacrifice. As our study differentiates the ease and political effectiveness of civic engagement, it also raises the question of whether female ministers might ever inspire women in aspects of civic engagement that pose risks or are dangerous. This question is important as scholars often debate the meaning and effectiveness of civic engagement - if participation such as voting and joining political parties does not drastically change politics, it may be that more risky or confrontational behavior is necessary. However, these are also the forms of civic engagement that women are least likely to employ. We do not yet understand well what leads women to engage in such acts nor whether female politicians play a role in inspiring action under these extreme circumstances.

Lastly, our data represent a cross-section of a specific time point. While we use the most up-to-date dataset to cross-nationally examine the relationship between women's representation in the cabinet and forms of political participation, we do not know whether the effects are constant over time. Indeed, we discuss reasons, such as the rise of internet activism, why the effect might change over time. Other dynamic effects might also exist. For example, as women habitually are found in these positions of political power, it may be that their effect as role models 
diminishes, particularly if they are identified less by gender or if gender roles shift as a result of their increased representation. This suggests the necessity of a close examination of how role model effect works at different points in time. As this research differentiates between women's leadership in the legislatures and in the cabinets, we hope it will also open the door to future research on how women political leaders matter as new generations of women increasingly participate in political activities.

\section{SUPPLEMENTARY MATERIAL}

To view supplementary material for this article, please visit http://dx.doi. org/10.1017/S1743923X16000490

Shan-Jan Sarah Liu is Instructor of Government at Smith College, Northampton, MA: shanjan.sarah.liu@gmail.com; Lee Ann Banaszak is Professor of Political Science at The Pennsylvania State University: lab14@ psu.edu

\section{REFERENCES}

Abramson, Paul R., and Ronald Inglehart. 1995. Value Change in Global Perspective. Ann Arbor: University of Michigan Press.

Annesley, Claire, Karen Beckwith, Isabelle Engeli, and Susan Franceschet. 2012. "Theoretical Perspectives on Gender and Executive Leadership." Presented at the Midwest Political Science Association, Chicago.

Annesley, Claire, and Francesca Gains. 2010. "The Core Executive: Gender, Power and Change. Political Studies 58 (5): 909-29.

Atkeson, Lonna Rae. 2003. "Not All Cues Are Created Equal: The Conditional Impact of Female Candidate on Political Engagement." Journal of Politics 65 (4): 1040-61.

Atkeson, Lonna Rae, and Nancy Carrillo. 2007. "More Is Better: The Influence of Collective Female Descriptive Representation on External Efficacy." Politics \& Gender 3 (1): 79-101.

Banaszak, Lee Ann. 2010. The Women's Movement Inside and Outside the State. Cambridge: Cambridge University Press.

Barnes, Tiffany D., and Stephanie M. Burchard. 2012. “'Engendering' Politics: The Impact of Descriptive Representation on Women's Political Engagement in Sub-Saharan Africa." Comparative Political Studies 46 (7): 767-90.

Bogdanor, Vernon. 1992. Proportional Representation: Which System? London: Election Reform Society of Great Britain and Ireland.

Borrelli, MaryAnne. 2002. The President's Cabinet: Gender, Power, and Representation. Boulder, CO: Lynn Rienner.

Bratton, Kathleen A., and Leonard P. Ray. 2002. "Descriptive Representation, Policy Outcomes, and Municipal Day-Care Coverage in Norway." American Journal of Political Science 46 (2): 428-37. 
Burns, Nancy, Kay Lehman Schlozman, and Sidney Verba. 2001. The Private Roots of Public Action: Gender, Equality, and Political Participation. Cambridge, MA: Harvard University Press.

Campbell, David E., and Christina Wolbrecht. 2006. "See Jane Run: Women Politicians as Role Models for Adolescents." Journal of Politics 68 (2): 233-47.

Carroll, Susan J. 1994. Women as Candidates in American Politics. Bloomington: Indiana University Press.

Caul, Miki. 2001. "Political Parties and the Adoption of Candidate Gender Quotas: A Cross-National Analysis." Journal of Politics 63 (4): 1214-29.

Celis, Karen, Sarah Childs, Johanna Kantola, and Mona Lena Krook. 2008. "Rethinking Women's Substantive Representation.” Representation 44 (2): 99-110.

Childs, Sarah, and Mona Lena Krook. 2008. "Critical Mass Theory and Women's Political Representation.” Political Studies 56 (3): 725-36.

Dalton, Russell J. 2008. Citizen Politics: Public Opinion and Political Parties in Advanced Industrial Democracies. Thousand Oaks, CA: Sage.

Davis, Rebecca Howard. 1997. Women and Power in Parliamentary Democracies: Cabinet Appointments in Western Europe, 1968-1992. Vol. 2. Lincoln: University of Nebraska Press.

Dahl, Viktor, and Håkan Stattin. 2014. "Beyond the Limits: Involvement in Illegal Political Activities." European Political Science Review 8 (1): 125-45.

Desposato, Scott, and Barbara Norrander. 2009. "The Gender Gap in Latin America: Contextual and Individual Influences on Gender and Political Participation.” British Journal of Political Science 39 (1): 141-62.

Dovi, Suzanne. 2014. "Political Representation." In The Stanford Encyclopedia of Philosophy, ed. Edward N. Zalta. http://plato.stanford.edu/archives/spr2014/entries/ political-representation/ (accessed June 26, 2016).

Earl, Jennifer, and Katrina Kimport. 2009. "Movement Societies and Digital Protest: Fan Activism and other Nonpolitical Protest Online.” Sociological Theory 27 (3): 220-43.

Earl, Jennifer, Katrina Kimport, Greg Prieto, Carly Rush, and Kimberly Reynoso. 2010. "Changing the World One Webpage at a Time: Conceptualizing and Explaining Internet Activism.” Mobilization: An International Quarterly 15 (4): 425-46.

Escobar-Lemmon, Maria, and Michelle M. Taylor-Robinson. 2005. "Women Ministers in Latin American Government: When, Where, and Why?" American Journal of Political Science 49 (4): 829-44.

Ewig, Christina. 2008. "Reproduction, Re-Reform and the Reconfigured State: Feminists and Neo-Liberal Health Reforms in Chile." In Beyond States and Markets: The Challenges of Social Reproduction, eds. Isabella Bakker and Rachel Silvey. New York: Routledge, 143-58.

Fox, Richard L., and Jennifer L. Lawless. 2004. "Entering the Arena? Gender and the Decision to Run for Office." American Journal of Political Science 48 (2): 264-80.

— . 2010. "If Only They'd Ask: Gender, Recruitment, and Political Ambition." Journal of Politics 72 (2): 310-26.

Franceschet, S. 2010. "Continuity or Change? Gender Policy in the Bachelet Administration." In The Bachelet Government: Conflict and Consensus in PostPinochet Chile, eds. Silvia Borzutzky and Gregory B. Weeks. Gainesville: University Press of Florida, 158-80.

Gallagher, Michael, and Paul Mitchell, eds. 2005. The Politics of Electoral Systems. Oxford: Oxford University Press.

Golder, Matthew. 2005. "Electoral System Type." In The Quality of Government Dataset Codebook, QOG Institute Quality of Government, University of Gothenburg. http:// 
www.qog.pol.gu.se/digitalAssets/1358/1358062_qog_codebook_v6aprll.pdf (accessed April 7, 2014).

Hawkesworth, Mary. 2003. "Congressional Enactments of Race-Gender: Toward a Theory of Raced-Gendered Institutions.” American Political Science Review 97 (4): 529-50.

Inglehart, Ronald. 1990. Culture Shift in Advanced Industrial Society. Princeton, NJ: Princeton University Press.

- 1997. Modernization and Postmodernization: Cultural, Economic and Political Change in 43 Societies. Princeton, NJ: Princeton University Press.

Inglehart, Ronald, and Pippa Norris. 2003. Rising Tide: Gender Equality and Cultural Change around the World. Cambridge: Cambridge University Press.

Inter-Parliamentary Union (IPU). 2009. "Women in National Parliaments." http://ipu.org/ wmn-e/world.htm (accessed January 14, 2014).

- 2015. "Women in National Parliaments." http://ipu.org/wmn-e/world.htm (accessed September 27, 2015).

Kahne, Joseph, Ellen Middaugh, and Danielle Allen. 2014. "Youth, New Media, and the Rise of Participatory Politics." In From Voice to Influence: Understanding Citizenship in a Digital Age, eds. Danielle Allen and Jennifer S. Light. Chicago: University of Chicago Press, 35-58.

Karp, Jeffrey A., and Susan A. Banducci. 2008. "Political Efficacy and Participation in Twenty-Seven Democracies: How Electoral Systems Shape Political Behaviour." British Journal of Political Science 38 (2): 311-34.

Kathlene, Lyn. 2001. “Words That Matter: Women's Voice and Institutional Bias in Public Policy Formation." In The Impact of Women in Public Office, ed. Susan J. Carroll. Bloomington: Indiana University Press, 22-48.

Kittilson, Miki Caul, 2005. "In Support of Gender Quotas: Setting New Standards, Bringing Visible Gains.” Politics \& Gender 1 (4): 638-45.

— . 2006. Challenging Parties, Changing Parliaments: Women and Elected Office in Contemporary Western Europe. Columbus: Ohio State University Press.

— . 2008. "Representing Women: The Adoption of Family Leave in Comparative Perspective." Journal of Politics 70 (2): 323-34.

Kittilson, Miki Caul, and Leslie Schwindt-Bayer. 2010. "Engaging Citizens: The Role of Power-Sharing Institutions. Journal of Politics 72 (4): 990-1002.

Krook, Mona Lena, and Diana Z. O'Brien. 2012. "All the President's Men? The Appointment of Female Cabinet Ministers Worldwide." Journal of Politics 74 (3): $840-55$.

Lawless, Jennifer L., and Richard L. Fox. 2005. It Takes a Candidate: Why Women Don't Run for Office. Cambridge: Cambridge University Press.

— 2015. Running from Office: Why Young Americans are Turned Off to Politics. Oxford: Oxford University Press.

Lijphart, Arend. 2012. Patterns of Democracy: Government Forms and Performance in Thirty-Six Countries. New Haven, CT: Yale University Press.

Lister, Ruth. 2003. Citizenship: Feminist Perspectives. 2nd ed. New York: New York University Press.

Maguth, Brad M. 2012. "Investigating Student Use of Technology for Engaged Citizenship in a Global Age.” Education Sciences 2 (2): 57-76.

Matland, Richard E., and Donley T. Studlar. 1996. "The Contagion of Women Candidates in Single-Member District and Proportional Representation Electoral Systems: Canada and Norway." Journal of Politics 58 (3): 707-33.

Mansbridge, Jane. 1999. "Should Blacks Represent Blacks and Women Represent Women? A Contingent 'Yes." Journal of Politics 61 (3): 628-57. 
Marx, David M., and Jasmin S. Roman. 2002. "Female Role Models: Protecting Women's Math Test Performance." Personality and Social Psychology Bulletin 28 (9): 1183-93.

McAdam, Douglas. 1986. Recruitment to High-Risk Activism: The Case of Freedom Summer. American Journal of Sociology 92 (1): 64-90.

— 1992. "Gender as a Mediator of the Activist Experience: The Case of Freedom Summer." American Journal of Sociology 97 (5): 1211-40.

McDonagh, Elaine. 2009. The Motherless State: Women's Political Leadership and American Democracy. Chicago: University of Chicago Press.

McGlenn, Nancy, and Meredith Reid Sarkees. 1997. "Style Does Matter: The Impact of Presidential Leadership on Women in Foreign Policy. In The Other Elites: Women, Politics, and Power in the Executive Branch, eds. MaryAnne Borrelli and Janet Martin. Boulder, CO: Lynne Rienner, 107-28.

Moore, Gwen, and Gene Shackman. 1996. "Gender and Authority: A Cross-National Study." Social Science Quarterly 77 (2): 273-88.

Norris, Pippa, and Mona Lena Krook. 2009. "One of Us: Multilevel Models Examining the Impact of Descriptive Representation on Civic Engagement. Presented at the Annual Meeting of the American Political Science Association, Toronto.

Nixon, Lucia A., and Michael D. Robinson. 1999. "The Educational Attainment of Young Women: Role Model Effects of Female High School Faculty.” Demography 36 (2): 185-94.

Norris, Pippa, and Joni Lovenduski. 1993. “If Only More Candidates Came Forward': Supply-Side Explanations of Candidate Selection in Britain." British Journal of Political Science 23 (3): 373-408.

Paxton, Pamela. 1997. "Women in National Legislatures: A Cross-National Analysis." Social Science Research 26 (4): 442-64.

Paxton, Pamela, and Sheri Kunovich. 2003. "Women's Political Representation: The Importance of Ideology." Social Forces 82 (1): 87-113.

Pearson, Kathryn, and Logan Dancey. 2011. "Elevating Women's Voices in Congress Speech Participation in the House of Representatives." Political Research Quarterly 64 (4): $910-23$.

Raudenbush, Stephen W., and Anthony S. Bryk. 2002. Hierarchical Linear Models: Applications and Data Analysis Methods. Vol. 1. Thousand Oaks, CA: Sage.

Reingold, Beth. 2000. Representing Women: Sex, Gender, and Legislative Behavior in Arizona and California. Chapel Hill: University of North Carolina Press.

Reynolds, Andrew. 1999. "Women in the Legislatures and Executives of the World." World Politics 51 (4): 547-73.

Schlozman, Kay Lehman, Nancy Burns, and Sidney Verba. 1999. "What Happened at Work Today? A Multistage Model of Gender, Employment, and Political Participation." Journal of Politics 61 (1): 29-53.

Schwindt-Bayer, Leslie A. 2010. Political Power and Women's Representation in Latin America. Oxford: Oxford University Press.

Schwindt-Bayer, Leslie A., and William Mishler. 2005. “An Integrated Model of Women's Representation." Journal of Politics 67 (2): 407-28.

Steckenrider, Janie S. 2013. "Angela Merkel: From Serendipity to Global Success." In Women as Political Leaders: Studies in Gender and Governing, eds. Michael A. Genovese and Janie S. Steckenrider. New York: Routledge, 226-55.

Verba, Sidney, Nancy Burns, and Kay Lehman Schlozman. 1997. "Knowing and Caring about Politics: Gender and Political Engagement." Journal of Politics 59 (4): 1051-72.

Verba, Sidney, Norman H. Nie, and Jae-on Kim. 1978. Participation and Political Equality: A Seven-Nation Comparison. Chicago: University of Chicago Press. 
Warwick, Paul V., and James N. Druckman. 2006. "The Portfolio Allocation Paradox." European Journal of Political Research 45 (4): 635-80.

Welch, Susan. 1977. "Women as Political Animals? A Test of Some Explanations for MaleFemale Political Participation Differences." American Journal of Political Science 21 (4): $711-30$.

Wiliarty, Sarah Elise. 2008. “Angela Merkel's Path to Power: The Role of Internal Party Dynamics and Leadership." German Politics 17 (1): 81-96.

Wolbrecht, Christina, and David E. Campbell. 2007. "Leading by Example: Female Members of Parliament as Political Role Models." American Journal of Political Science 51 (4): $921-39$.

Wolfsfeld, Gadi, Karl-Dieter Opp, Henry A. Dietz, and Jerrold D. Green. 1994. "Dimensions of Political Action: A Cross-cultural Analysis." Social Science Quarterly 75(1): 98-114.

World Bank. 2009. “Labor Force Participation Rate, Female.” http://data.worldbank.org/ indicator/SL.TLF.CACT.FE.ZS (accessed January 15, 2014).

World Values Survey (WVS). 2014. "World Values Survey." http://www.worldvaluesurvey. org (accessed June 6, 2015). 